\title{
DIGITAL TECHNOLOGIES IN HR MANAGEMENT
}

\author{
Yuliia Sotnikova ${ }^{1}$, Galyna Nazarova ${ }^{2}$, Nikita Nazarov ${ }^{3}$, Hanna Bilokonenko ${ }^{4}$ \\ ${ }^{1}$ Assoc. Prof., PhD (Econ.) Simon Kuznets Kharkiv National University of Economics. \\ Nauky Ave. 9a. 61166 Kharkiv, Ukraine. Phone number +38 (063) 6202344, E-mail yuliia.sotnikova@hneu.net \\ ${ }^{2}$ Prof. Dr.Sc. (Econ) Simon Kuznets Kharkiv National University of Economics. \\ Nauky Ave.9a.61166 Kharkiv, Ukraine.E-mail gnazarova@hneu.net \\ ${ }^{3}$ Assoc. Prof., PhD (Econ.) Simon Kuznets Kharkiv National University of Economics. \\ Nauky Ave.9a.61166 Kharkiv, Ukraine.E-mailnikita_nazarov_88@ukr.net \\ ${ }^{4}$ Assoc. Prof., PhD (n Econ.) Simon Kuznets Kharkiv National University of Economics. \\ Nauky Ave.9a.61166 Kharkiv, Ukraine.E-mail hanna.bilokonenko@hneu.net
}

Received 1102 2020; Accepted 21122020

\begin{abstract}
The aim of the article is to analyze current technologies trends in the field of personnel management. The introduction of digital technologies in the activities of enterprises in different countries of the world has been analyzed. A comparative analysis of traditional and digital technologies allowed to determine the effectiveness of the latter has been conducted. Modern trends in HR management have been distinguished. SWOT-analysis of digitalization of staff processes at the enterprises which determine prospects for further using of digital technologies in business has been conducted.
\end{abstract}

Keywords: digital technologies, digitalization, HR-Management, social media, SWOT-analyses.

JEL Codes: O15, L84, L86.

\section{Introduction}

The first decade of the XXI century was marked by the entry of the world into a new technological era characterized by the blurring of the boundaries between physical, biological and digital technologies. In these new realities, digital technologies are at the core of the post-industrial innovation economy. The whole range of high technology in question includes artificial intelligence, unmanned transportation, 3D printing, nanotechnology, biotechnology and more.

The development of new technologies, especially digital, is accompanied by systemic changes in all spheres of business, society and politics, as well as the emergence of more modern forms of organization of work of the government, public and private sectors of the economy, which guarantee transparency of the public environment. In fact, there is a rapid birth of a new generation of economy, dubbed the digital economy and based mainly on the introduction and use of digital technology in all areas of economic activity.

However, despite the fact that the term "digital economy" today is firmly entrenched in our lives and is widely used in the scientific literature, programs and various documents developed by both the state and business. Restraining factors for lagging countries are: low level of technology development and underdeveloped digital infrastructure, which is explained by inefficient use of factors of production, lack of human resources (imperfection of the system of training of research, engineering and technical capabilities, competitiveness of products), low competitiveness of products and IT specialists.

Considering economic security issues, it is fundamentally important for developing countries to keep up with developed countries and accelerate the adoption of digital technologies.

Copyright (C) 2020. Published by Vytautas Magnus University. This is an open access article distributed under the terms of the Creative Commons Attribution Non-Commercial 4.0 (CC BY-NC 4.0) license, which permits unrestricted use, distribution, and reproduction in any medium provided the original author and source are credited. The material cannot be used for commercial purposes. 
This issue is especially relevant for the real sector of the economy, the competitiveness of manufactured products and the position of the country in the world high-tech markets, which form the preconditions for sustainable development, will depend on the level of permanent development.

Many scientists have been engaged in concepts of spreading of digitalization in different spheres of activity: K. Kuprina, D. Khazanova, K. Lapina-Kratasyuk, A. Halapsis, T. Onore, J.-P. de Clerck, G. Tard, F. Bass, F. Ratzel, L. Frobenius, E. Rogers, D. Hawkins, I. Zolotaryov and others.

The aim of this work is to analyze current technologies trends in HR management and outline further prospects for its development.

The research objective is digital technologies.

The research subject is to identify trends in working with staff by using digital technologies in context their abilities to improve the efficiency of HR management.

Research methods: comparative analysis we have used to distinguish the differences between features of personnel management, which is based on traditional and digital approaches. Statistical analysis has been used in order to demonstrate the main ways of using digital technologies at enterprises, and its advantages. SWOT-analysis has been used to find the ways of further development of digital technologies at domestic labour market.

Elements of scientific novelty. The authors have combined the approaches developed in the literature on the interpretation of the term "digitalization" and formulated it as a way of doing business that provides new competitive advantages for the company through the development of innovation and creativity.

Practical significance. The authors grouped the main current trends in the field of personnel management and identified software products that help to implement a function of the personnel management system more effectively through the use of modern digital technologies.

\section{Research results and their explanation}

The definition of "digital" comes from the Latin-numbers. Accordingly, the term "digitalization" comes from the English "digitalization". At the same time, K. Lapina-Kratasyuk emphasizes that this term covers a wider range of meanings, due to the fact that "it is in the European and American research traditions that the consequences of the transition from analog to digital coding of information began to be studied not only as technological but also as social, cultural and anthropological processes" (Headhunter research service, 2018).

According to Kuprina and Khazanova (Kuprina, 2016), digitalization is a way to digitalize any kind of information. This approach is extended by Halapsis (Halapsis, 2016), who considers digitalization not as a method, but as associated with the tendency to bring into electronic form a variety of types of information used by man, a process he defined as "digitization of being. Indeed, the Oxford Dictionary of the English Language describes digitalization as "the action or process of digitization; conversion of analog data (images, video and text materials) into digital form" (Lexico. Oxford English and Spanish Dictionary, 2020).

Some scholars argue that digitalization is "the introduction or increased use of digital and computer technology by organizations, industries, countries, and so on".

The position of Clerck (2019), who notes that the use of digital data separated from physical media to automate work and business processes should also be seen as a manifestation of the digitalization of business structures.

We support Honore's approach (Honore, 2016), which states that digitalization is necessary primarily to optimize the business with software and IT solutions that will help make it simpler, more economical and better in the context of providing services to customers and meeting their needs. 
The World Davos Economic Forum defines in analytical materials a list of digital technologies that should be used by businesses: cloud and mobile technologies, blockchain, virtualization technologies, identification, artificial intelligence, biometric technologies, augmented reality technologies, additive (3D-printing), etc. They make it possible to transfer business processes to a new quality and accelerate the economic growth of enterprises. In fact, digitalization involves a radical change in organizational design, models and methods of management, centers of responsibility.

That is, digitalization is not only the use of digital technologies, but primarily a change in thinking, leadership style, incentive system and the adoption of new business models.

At the same time, we emphasize that digitalization involves the integration of digital technologies in all areas of business, which leads to qualitative radical changes in the functioning and behavior of the enterprise. In essence, digitalization is a change in the approach to doing business (Headhunter research service, 2018). In order to be commercially successful in the new conditions of general digitalization, the company needs to develop new products using digital channels of the enterprise. That is, digitalization, by its purpose, provides new types of innovation and creativity in a particular field, rather than simply improving or supporting traditional methods (Lexico. Oxford English and Spanish Dictionary, 2020).

Mostly, scientists are unanimous in the opinion that digitalization generates new competitive advantages for the company (Guseva, 2018). Markova and Kuznetsova argue that the competitive advantage of the company is its market position, which allows it to overcome competition and attract buyers. Other scientists argue that competitive advantage is a set of key non-competitive success factors that help ensure the company a stable leading competitive position in the market for a certain period.

Therefore, we could say that digitalization is the way of doing business that provides new competitive advantages for the company through the development of innovation and creativity.

Transition from a traditional "product" company to a technological one, the search for new management models based on the formation of Digital - strategy provides such peculiarities of development of modern companies:

- consumer demands are changing: speed and convenience of buying goods / services, checking recommendations, online payment;

- $\quad$ speed - the need for real-time decision-making;

- $\quad$ the need for storage, processing and analysis of huge amounts of data (Big Data) and the priority of information security;

- $\quad$ cross-functional work to increase efficiency;

- $\quad$ changes in sales: from the seller-person to the seller-robot;

- $\quad$ transition from "target audience" to personalization;

- $\quad$ intermediary platforms for high-tech business processes;

- digital business transformation - digitalization: platforms, services, mobile applications, social networks;

- $\quad$ digital marketing is an integral part of marketing strategy.

These general trends in business development have a significant impact on the features of working with staff, among which are the following:

- company philosophy - agility (changing staff needs in relation to the content and working conditions, the shift of balance towards freedom);

- training of non-employees of the company (HR becomes the engine of flexible organization of work and forms of employment);

- transformation of HR function into a real business partner (intellectualization to increase efficiency, robotics and cognitive technologies); 
- blurring the boundaries of $\mathrm{HR}$ as a separate function: active involvement of functional managers in HR-processes and integration of personnel management processes into business processes (Decision-making based on the HR system - metrics and analytics in dynamics);

- $\quad$ needs for new HR-competencies: automation, robotics, Digital (HiPo Management).

These global trends lead to the formation of a new concept: HR Digital as a feature of working with staff and the base of modern digital technologies, and which is manifested in:

- the need for access to social networks and corporate resources from personal gadgets;

- $\quad$ social interaction with multimedia opportunities between project members and $360^{\circ}$ feedback to connect with managers;

- $\quad$ availability of all types of training (video, audio, courses, presentations) from any digital source;

- mobile employer - new ways of effective recruitment;

- $\quad$ use and integration of third-party data on employees and applicants from social media platforms;

- $\quad$ use of artificial intelligence and big data in talent management;

- $\quad$ integration of Big Data with HR - Digital;

- mobile applications as the main platforms for HR tools.

The experience of implementing such technologies in the process of HR management iat an enterprise is up-to-date. According to the results of research of international consulting companies that conduct research on changes in the labor market (Deloitte, E\&Y, KPMG, Harvey Nash), the introduction of digitalization in the personnel management system in enterprises is of particular importance and relevance. Every year more and more companies are automating the HR function, thus simplifying and making the recruiters and HR managers more efficient. A survey of respondents was conducted by Deloitte University Press, who assessed the importance of the introduction of digital technologies in personnel management (Fig. 1).

Respondents from countries such as India, Brazil and Mexico have the highest level of need for the introduction of digital technologies in the activities of personnel management services. Today, the HR center has shifted towards building the organization of the future. Companies hire young, experienced digital employees to do things on their own and share information in a transparent way. They want to have an integrated digital experience designed for teams, efficiency and empowerment, and HR is expected to deliver.

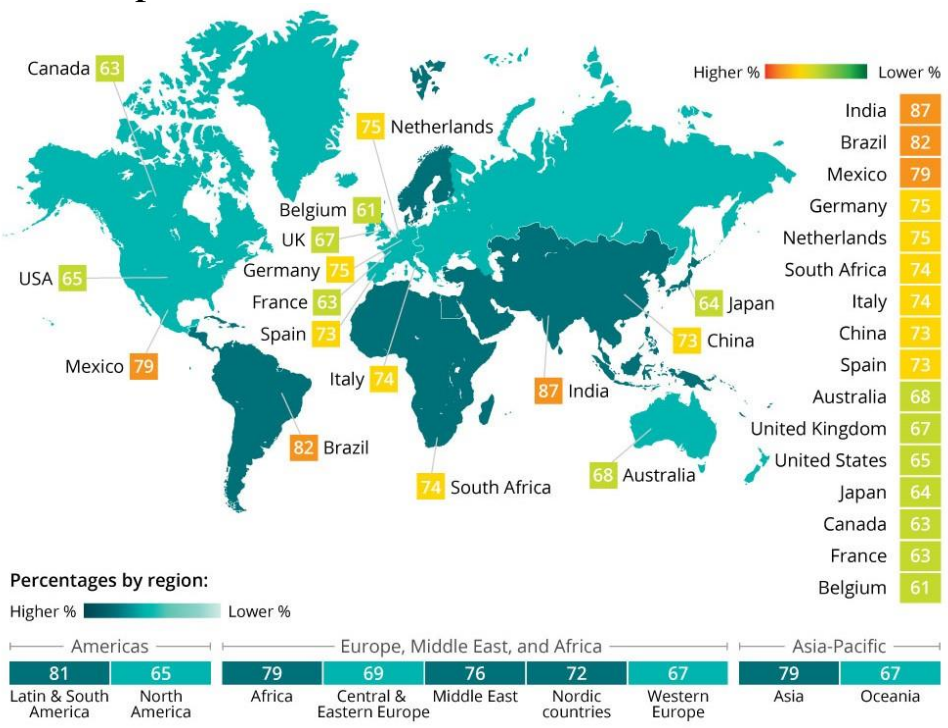

Figure 1. The importance of implementing digital technologies in HR management in the world (Deloitte, 2017) 
Let's consider the difference between current models of HR services and digital HR to understand how radical and profound the digital transformation of HR will be (Table 1).

Table 1. Comparative characteristics of the current HR - model and digital HR (Rudakova, Danilevich, Schetinina, \& Kasyanenko, 2020)

\begin{tabular}{|c|c|}
\hline Current HR model & Digital HR \\
\hline $\begin{array}{l}\text { HR departments focus on the process of } \\
\text { designing and harmonizing standard HR processes }\end{array}$ & $\begin{array}{l}\text { HR departments focus on optimizing employee productivity, } \\
\text { engagement, teamwork and career growth }\end{array}$ \\
\hline $\begin{array}{l}\text { Outdated methods of creating and implementing } \\
\text { HR metrics are used }\end{array}$ & $\begin{array}{l}\text { HR uses innovation, selects specialized software that suits the } \\
\text { needs of the organization, develops innovative applications and } \\
\text { manages platforms for metrics }\end{array}$ \\
\hline $\begin{array}{l}\text { Paper documentation and focus on the } \\
\text { implementation and integration of the enterprise } \\
\text { resource planning process }\end{array}$ & $\begin{array}{l}\text { Digital form, go beyond simple enterprise resource planning to } \\
\text { develop digital capabilities and mobile applications with a focus on } \\
\text { "productivity" }\end{array}$ \\
\hline $\begin{array}{l}\text { Process - centered thinking, focus on improving } \\
\text { existing processes }\end{array}$ & $\begin{array}{l}\text { Use of fundamentally new digital technologies: chats, mobile } \\
\text { applications, business cases and more. }\end{array}$ \\
\hline Partial flexibility, work with the target audience & Personalization, full mobility and flexibility \\
\hline HR service centers are focused on self-service & $\begin{array}{l}\text { Operations Centers, HR focuses on helping employees to make } \\
\text { their work more productive }\end{array}$ \\
\hline Periodic reports & Real-time operational reports \\
\hline Analytical additions & Integrated HR-platforms (policies, processes, systems, operations) \\
\hline
\end{tabular}

This approach is a completely new way of thinking about personnel decisions. While the main part of the transition is the translation of obsolete systems into the cloud, there is the introduction of fundamentally new digital technologies, integrated mobile applications and realtime operational HR. The principles of behavioral economics, the use of analytics, and constant iterations of design also underlie these efforts. In order to be successful in the new paradigm, HR teams are likely to need to work with IT, adapt design thinking, use integrated analytics, and carefully analyze software vendor decisions. This is a new world for HR technologies and project teams that will open up new career opportunities to transform the impact of HR on business.

The need forms the proposal: business digitalization has led to the emergence of a new cluster of product development and digital management services. To confirm the relevance and necessity of implementing digital technologies in HR management procedures, we present the results of a survey conducted by the leader of on-line resources for job search and recruitment, HeadHunter (Headhunter research service, 2018): out of 310 representatives of companies engaged in HR, the structure of using of Digital tools in their work has been formed (Fig. 2,3).

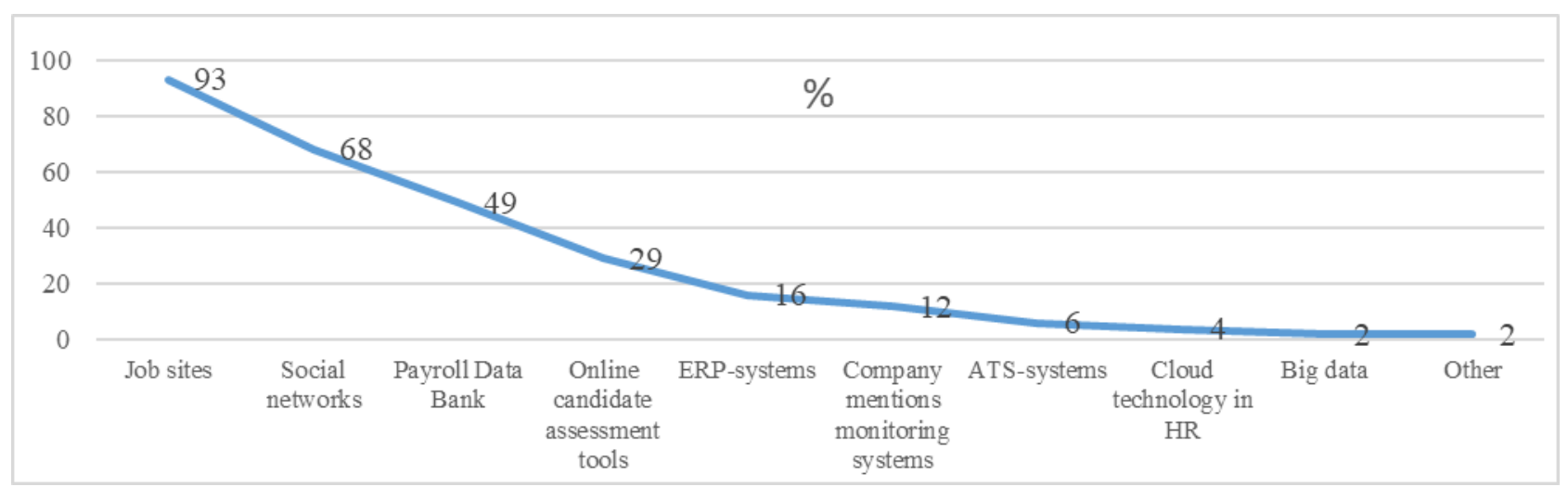

Figure 2. Results of survey on on-line resources for job search and recruitment (HeadHunter, 2018) 


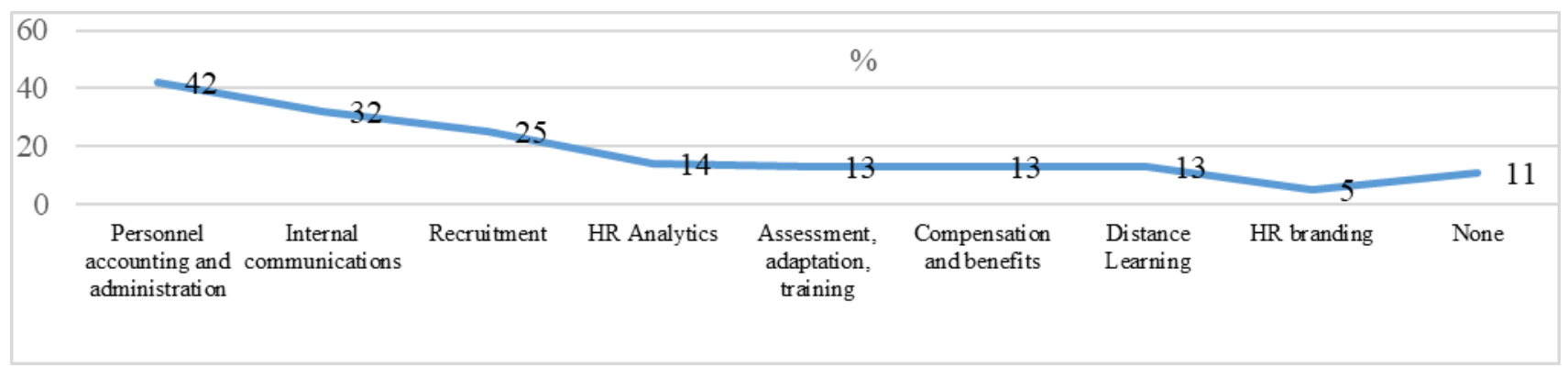

Figure 3. HR - processes that are automated in companies of developing countries (HeadHunter, 2018)

According to the research, the main advantages of using digital technologies are: accuracy and availability of data ( $42 \%$ of respondents), ability to connect different business processes (39\%) and manage remote employees (35\%), as well as synchronize HR work - departments with other business units (28\%) (HeadHunter, 2018).

Among a suite of digital tools, companies most often use PocketPCs, social networks and online tools to evaluate candidates. To a lesser extent, cloud technologies, social media and media mentoring systems, ERP and ATS systems, as well as Big Data are involved. Most often, HRs use Desktop versions of resources, but mobile versions are becoming more widely available (Sotnikova, 2018).

Thus, according to the results of the study, it is possible to conclude that the use of digital technologies in the process of human resources management is effective, namely: it allows to organize a convenient digital environment for staff. For example, personnel adaptation processes can be automated with artificial intelligence. A chatbot can answer questions, familiarize newcomers with the organization's internal documents, provide the necessary information and resources for a comfortable entry (Dvorskaya, 2018).

Also, the artificial intelligence system is able to study and analyze the skills, behaviors and actions of the most effective employees, and build educational trajectories for staff based on this data (Dvorskaya, 2018). The introduction of virtual and augmented reality into the staff training process can take the quality of training to a new level, and make the process interactive and engaging. This technology allows to simulate real-world situations in the virtual space, with the help of which the complete immersion of staff in a training environment in which they have the opportunity to practice their skills. Cloud technologies allow to upload information to a virtual space that is accessible to each employee. In this way, for example, you can organize staff training in the form of an online platform containing a catalog of courses and reflecting the success of each employee. Based on the blockchain, it is possible to create a service that contains resumes, certificates, diplomas and professional achievements of applicants, which will help to reduce the time spent by HR professionals to find suitable candidates and check the accuracy of information about them.

The introduction of digital technologies in HR management will help streamline the purposeful activities of the HR department and company management, use available archival documentation from time to time, but constantly, in daily work, find necessary information in one click, reduce the time traditionally used on reporting.

It is possible to see the greatest use of ICT are in small businesses with up to 50 people. They are more flexible, respond quickly to changes in the environment and adapt to modern trends. In second place, respectively, medium-sized enterprises, and in third place are large companies with a large number of people, complex organizational structure and significantly inert to changes in the environment. 
We conducted more detailed analysis of modern trends in working with staff by using digital technologies (Table 2) due to their abilities to improve the efficiency of personnel management.

\section{Table 2. Modern trends in working with staff}

\begin{tabular}{|c|c|}
\hline Trend & The software product that implements it \\
\hline $\begin{array}{c}\text { Automatically fill in candidate profiles based on their pages in } \\
\text { professional networks }\end{array}$ & Linkedin \\
\hline Anonymity in pre-selection & jobsnap, djinni.co \\
\hline Use of social networks for selection of candidates & Telegram, Facebook, Twitter \\
\hline Automation of personnel selection & Applicant Tracking Systems - Jobscan \\
\hline $\begin{array}{c}\text { Automation of recruitment processes - onboarding, adaptation, } \\
\text { training, development, internal document flow of the company }\end{array}$ & ZOHOPeople, BambooHR, HURMA \\
\hline Forecasting and HR - analytics & - \\
\hline Monitoring the mood of employees & HURMA, eNPS, Gallup Q12 \\
\hline Combination of recruitment and HR processes & Google Calendar \\
\hline Integration with calendars, meeting management & Skype, Hangouts, Zoom \\
\hline Corporate training & Codility, TESTDOME, Tests4Geeks, PROMETHEUS \\
\hline Digitization of recruitment &
\end{tabular}

Source: own research

There is no single criterion for determining the effectiveness of software product/platform. It all depends on the specifics of the company, the material resources that can be used for implementation and operation, as well as the purpose of use.

However, the digitalization of HR-processes has not only advantages and benefits, but also has disadvantages and risks. SWOT-analyses of the implementation of digital technologies in HR management is presented at the Fig. 4.

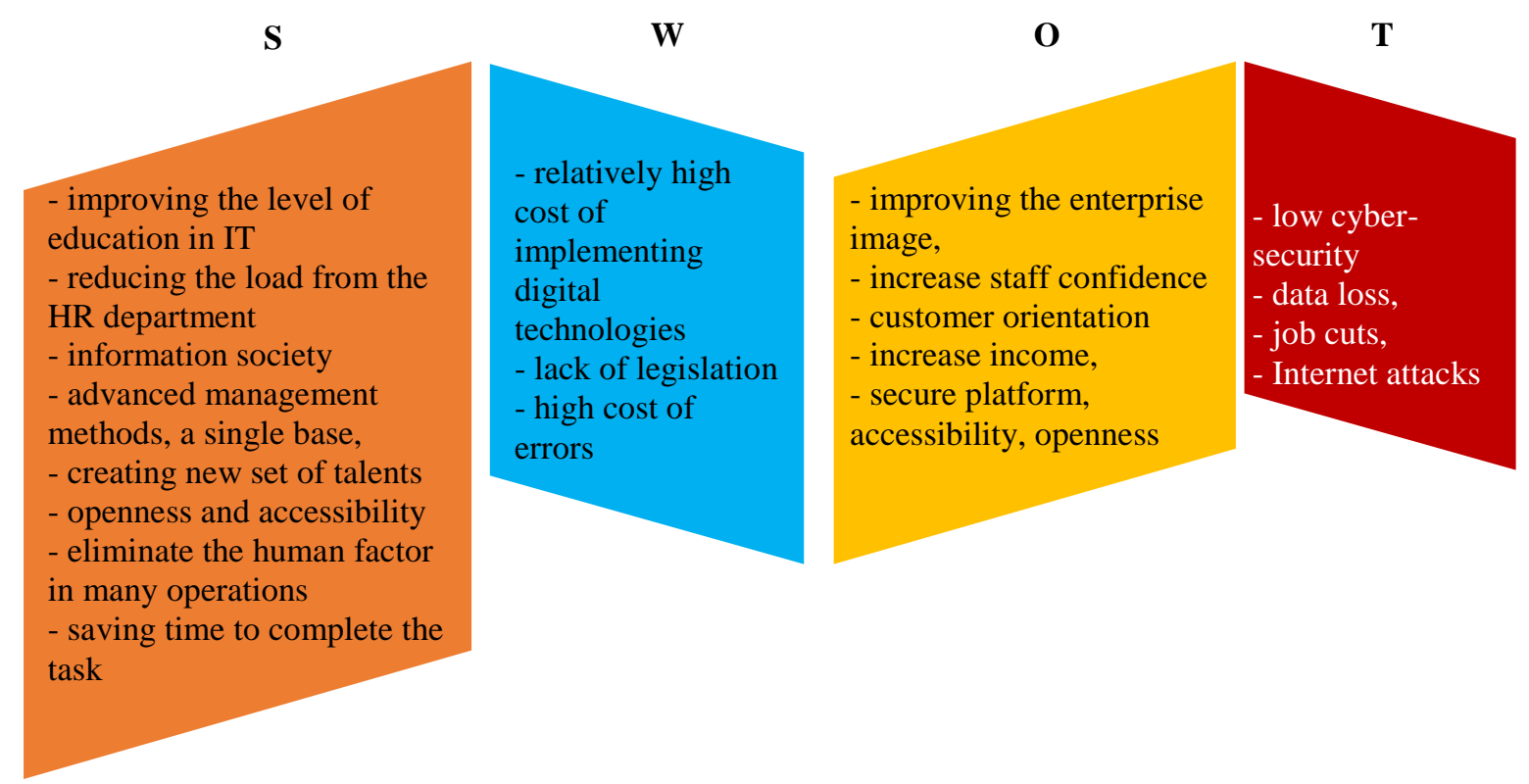

Figure 4. SWOT-analyses of digitalization of staff processes at the enterprises

Source: own research

To begin with, let's analyze strengths (positive aspects of the introduction of digital technologies in HR management).

For example, automation and optimization of work processes reduces the workload of the HR department, and HR specialists themselves get effective tools for working with staff through digitalization. Personnel management costs are reduced because there is no need to inflate HR - 
many routine operations can be performed automatically, for example, using artificial intelligence. This is especially true if the company is large. For such companies, the introduction of digital technologies allows to keep only dozens of employees in the HR-staff, which saves the company a lot of money. In addition, digitization eliminates the human factor in many operations, because programs, applications and services always meet clear standards, rarely fail and make mistakes, they are not prone to fatigue, and their performance is not dependent on many factors, as in the case with a human. And another advantage is saving time. One program is able to perform a significant amount of work in incomparably less time than if the work was performed by a person.

Among the disadvantages are the relatively high cost of implementing digital technologies. Some organizations do not have a sufficient budget to modernize and automate HR processes. However, it should be noted that the cost of digitalization should be considered as a long-term investment that will not only pay off, but also bring future profits to the business. Another disadvantage is the risk of job cuts that require medium and low skills due to full automation of work processes. However, job cuts due to process automation companies can give their employees retraining and realize themselves in the field of activity that interests them most. The problem in the implementation of this program may be the resistance of employees, in particular, the older generation, to change and insufficient motivation of staff to master the competencies of the digital economy and participate in the development of digitalization of the organization (Vakulenko, 2016)

Another disadvantage is the high cost of errors. Unfortunately, no system is immune to errors, and even innovative technologies can fail. A small mistake made when constructing algorithms can lead not only to the loss of financial resources, but also to the loss of important information and data. In addition, when digitizing HR processes, special attention should be paid to digital security issues, as the information presented in cyberspace is often subject to cyber attacks of various kinds.

\section{Conclusions}

Thus, the introduction of digital tools in the personnel management system is the key to successful business operations in a modern information environment. This will make the process of managing people at the enterprise more transparent, motivating, aimed at achieving specific goals that take into account both the interests of each individual employee and the overall strategy of the enterprise.

Thus, reducing the complexity of HR-functions; accelerating management and personnel decisions; improving the quality of analytical data; ability to forecast for current and strategic periods; coverage of employees who are anywhere in the world; access to state-of-the-art technology solutions and personal development planning capabilities is just a non-exhaustive list of Digital's opportunities for efficiency in HR management.

\section{References}

Bersin, J., Pelster, B., Schwartz, J., Van Der Vyver, B. (2017). Rewriting the rules for the digital age. 2017 Deloitte Global Human Capital Trends. Deloitte University Press, United States. - Retrieved from https://www2.deloitte.com/content/dam/Deloitte/global/Documents/HumanCapital/hc-2017-global-human-capital-trends-gx.pdf [24.10.2020]

De Clerck, J.-P. (2019). Digitization, digitalization and digital transformation: the differences. - Retrieved from https://www.i-scoop.eu/digital-transformation/digitization-digitalization-digital-transformation-disruption/ [24.10.2020]

Dvorskaya, E.V. (2018). AI in HR: competition with man or mutually beneficial cooperation. - Retrieved from https://vc.ru/future/35297-ii-v-hr-konkurenciya-s-chelovekom-ili-vzaimovygodnoe-sotrudnichestvo [24.10.2020]

Guseva, O.Yu., Legominova, S.V. (2018). Digitalization - as an tool for improvement of business processes, their optimization // Economy. Management. Business, Vol.1: 33-39.

Halapsis, A.V. (2016). Globalization and the metrics of history. -Retrieved from Alex V. Halapsis Web site: http://halapsis.net/globalizatsiya-i-metrika-istorii. [24.10.2020] 
HeadHunter Research Service: Artificial intelligence will completely change the role of HR in companies. Retrieved from https://hr-elearning.ru/issledovanie-headhunter-iskusstvennyy-intellect-izmenit-rol-hr/. [24.10.2020]

Honore, T. (2016). Digitization is not an intangible business development. - Retrieved from https://cdn2.hubspot.net/hubfs/494838/United\%20States/Downloads/Columbus-5-Articles-on-Disruption-US.pdf [24.10.2020]

Kuprina, K.A., Khazanova, D.L. (2016). Digitalization: concept, prerequisites and spheres of application. // Bulletin of scientific conferences, Vol.5, Is.9: 259-263.

Lexico. Oxford English and Spanish Dictionary, Thesaurus, and Spanish to English Translator. - Retrieved from https://en.oxforddictionaries.com/definition/digital [24.10.2020]

Oxford English Dictionary. - Retrieved from https://www.oed.com [24.10.2020]

Ponomareva, E. (2016). 15 consumer trends coming from the West // Marketing. - Retrieved from http://www.executive.ru/management/marketing/198581215potrebitelskih-trendo vnastupauschihszapada?scrolltop=2377. [24.10.2020]

Prokhorenko, D.A. (2016). HR 3.0. When a resource becomes capital. - Retrieved from https://www.hrsummit.ru/ru/konferentsiya. [24.10.2020]

Rudakova, S.G., Danilevich, N.S., Schetinina, L.V., Kasyanenko, Y.A. (2020) Digital HR - the Future of Human Resources Administration // Business inform, Vol.1: 265-270.

Shchukina, A.A. (2016). Digital-Technology in Recruitment // Vector economy, Vol. 6: 50-60.

Sotnikova, Yu.V., Stepanova, E.R., \& Kasmin, D.S. (2018) The Transformation of Employment Forms in the Context of the Information Society of $21^{\text {st }}$ Century // Business inform, Vol. 4: 191-197.

State Statistics Service of Ukraine (2018) // Achievements in the field of communications in 2018. Available from State Statistics Service of Ukraine Web site: http://www.ukrstat.gov.ua [24.10.2020] 